MACIEJ JABŁOŃSKI

Kazimierz Wielki University in Bydgoszcz

\title{
Apparent Activities in Special Education. A Critical Analysis of Core Curriculum
}

\begin{abstract}
Maciej Jabłoński, Apparent Activities in Special Education. A Critical Analysis of Core Curriculum. Interdisciplinary Contexts of Special Pedagogy, no. 26, Poznań 2019. Pp. 103-124. Adam Mickiewicz University Press. ISSN 2300-391X. e-ISSN 2658-283X. DOI: https://doi.org/10.14746/ikps.2019.26.05

The topic discussed herein concerns a particular deconstruction of the core curriculum in primary special schools carried out by means of a critical analysis of this document. On the grounds of this analysis, the article shows the consequences of apparent actions that are taking place in special schools, which in consequence lead to violence, perpetuating negative stereotypes and stigmatisation of students with intellectual disabilities.
\end{abstract}

KEY WORDS: Apparent actions, violence, intellectual disability, social competences, civic competences

\section{Introduction}

In order to educate students in the belief that everyone has the right to freedom, it is necessary to get acquainted with the principles of democracy and the processes of democratisation of the system of education as well as with the close links between educational and political systems. While democratic education should prepare for the actual application of democracy, educational activity should 
be linked to fair, effective and democratic practice. ${ }^{1}$ However, one should bear in mind that "(...) teaching students about democracy does not necessarily make democrats out of them; this can be achieved through practical experience derived from a democratically established school". ${ }^{2}$ That is why, in a democratic state, the school has (or rather should have, as I believe it has lost this ability) the fundamental role in building foundations for the universal awareness of these ideals, without which there can be no democracy. It is precisely here that teachers should contribute to the acquisition of social and civic competences by students, among other things, by implementing the objectives set out in the curriculum.

Knowledge of these competences and understanding their role in building the identity of people with disabilities in a democratic state constitutes nowadays a particularly important issue. The problem regarding education of students with disabilities, ${ }^{3}$ regardless of the place of education - be it is a special school, integrated school, state school or family home - is of great importance or even seriousness. The aim of this education is, inter alia, to "build the student's identity, develop their autonomy and dignity, adjust them to

${ }^{1}$ E. Faure, Uczyć się, aby być (Learning to Be. The World of Education Today on Tomorrow), PWN, Warsaw 1975 p. 209.

2 B. Śliwerski, Meblowanie szkolnej demokracji (Furnishing School Democracy), Wolters Kluwer, Warsaw 2017, p. 166.

${ }^{3}$ See, inter alia: I. Chrzanowska, Problemy edukacji dzieci i mtodzieży z niepetnosprawnością: regionalna specyfika czy ogólnopolska tendencja (Educational Problems of Children and Young People with Disabilities: Regional Specificity or National Tendency), Oficyna Wydawnicza "Impuls”, 2010; Rozwój i funkcjonowanie osób niepetnosprawnych. Konteksty edukacyjne i prawne (Development and Functioning of People with Disabilities. Educational and Legal Contexts), ed. Z. Gajdzica, Oficyna Wydawnicza „Impuls", Kraków 2007; B. Jachimczak, Gotowość nauczycieli szkót ogólnodostępnych do pracy z uczniem o specjalnych potrzebach edukacyjnych (Willingness of teachers at public schools to work with students with special educational needs), [in:] Miejsce Innego we wspótczesnych naukach o wychowaniu - wyzwania praktyki (The Place of Other in Modern Educational Sciences. The Challenges of Practice), ed. I. Chrzanowska, B. Jachimczak, Wydawnictwo Satori, Łódź 2008; A. Krauze, Wspótczesne paradygmaty pedagogiki specjalnej (Contemporary Paradigms of Special Needs Education), Oficyna Wydawnicza „Impuls”, Kraków 2010. 
the functioning of society and to the understanding and observance of social norms, and in particular to equip them with such skills and knowledge that will enable them to exercise their freedom and human rights to the best of their ability and to perceive themselves as independent people". 4 Here, we have to pose a vital question. Namely: do the contents of the core curriculum, which in their formal and legal assumptions serve the development of students with disabilities, really compensate and equalize development opportunities for them, at least in terms of acquiring social and civic competences? Or maybe, the activities that can be found in the proceedings of both institutions co-organising the special needs education system and individual persons participation in this system directly or indirectly (teachers, therapists, directors, clerks, students, parents) are of an apparent nature thus rendering these opportunities equalized only ostensibly? ${ }^{5}$

I subjected the analysis of the core curriculum to critical "deconstruction" by means of analytical categories created by Violetta Kopinska, ${ }^{6}$ which are the result of a three-step process, i.e.:

- firstly, it is based on documents that should be taken into account when establishing the core curriculum for general education at European and national level;

- secondly, it is created on the basis of literature on the subject, which makes it possible to avoid the mistake of constructing a catalogue that is too narrow, one-sided, specific or perhaps "politicized";

${ }^{4}$ Appendix No. 3 to the Regulation of the Minister of National Education of 14 February 2017, item 356. p. 211, i.e. the Primary School Curriculum for students with moderate or severe intellectual disabilities.

${ }^{5}$ Cf. K. Parys, Zjawisko pozoru w systemie ksztatcenia uczniów niepetnosprawnych próba identyfikacji i propozycje rozwiązań (An Attempt at Identifying the Phenomenon of Pretense in the Education of Students with Disabilities and Proposals for Solutions). Interdyscyplinarne Konteksty Pedagogiki Specjalnej no. 4/2014, 2014, pp. 29-30.

${ }^{6}$ See: Kompetencje społeczne i obywatelskie. W podstawach programowych ksztatcenia ogólnego. Analiza krytyczna (Social and Civic Competences. In the Core Curriculum of General Education. A Critical Analysis), ed. V. Kopińska, H. Solarczyk-Szwec, Wydawnictwo Naukowe Uniwersytetu Mikołaja Kopernika, Torun 2017. 
- thirdly, by using open encoding, it is adapted to the tested sample and at the same time is not limited to the codes resulting from the core curriculum, which in turn makes it possible to identify those learning outcomes which are not included in the core curriculum and which are part of social and civic competences. ${ }^{7}$

This shall give the possibility to see if the actions of the message provider (teachers, tutors) as the implementer of the core curriculum are doomed to failure. The question remains, however, of whether the contents of the message have a chance to equip the student with the necessary social and civic competences.

\section{Apparent actions as systemic violence}

Jan Amos Comenius wrote: “(...) Since we are all born, this must be accomplished that at the end of the day no one shall regret the fact of coming to this world. And how can that be done? (...) First of all, by making no one live like a dull creature but heed the dictate of reason: everyone is endowed with its light, but to use what everyone has, not everyone knows how - unless he learns it. Therefore, he must be taught. Otherwise, it shall be a testament of stupidity (...). And one should not only wish that people would not become dull, but also that they should become as witty as possible. (...) because we must not wish to deprive any human being of his humanity through degradation, we must wish that no human being should be left without education: since for people without education, the easiest thing to do - which is inherent in human nature - is to de-

7 There may be doubts whether the analytical categories proposed by Violetta Kopińska are adequate for the analysis of the core curriculum of a special needs school. I still have them myself. However, the general and special curriculum basis was developed on the grounds of the same materials as the MEN documentation, and social and civic competences are universal competences, i.e. they are independent of whether we have or do not have any disabilities. 
grade".${ }^{8}$ The words of the classic become more and more up-to-date for me, when I undertake to continue his discussion asking - following in Maria Dudzikowa's footsteps - the following questions about the essence of apparent actions:

"1) What terms can/should we examine the categories of apparent actions? In what theories or conceptions can we place the term of apparent actions? Who/what can/should be the object of studies so as to identify apparent actions? With what indices, measured in what way? Using what techniques? 2) Are the practices connected with widely understood education apparent? Which of them? To what degree? What is the scale and dominant form of apparent actions at the level of macro- and microphenomena? What are the grounds and consequences? What institutional/awareness/cultural terms occur? 3) Which of the symptoms and mechanisms of apparent actions described by Jan Lutyński and regarding the past system were subject to weakening in the area of education and which survived despite the systemic change? Can we see - and if yes in which areas connected with education as a system and a process - the occurrence of new examples of apparent actions and what is the mechanism of their formation? In what situations can we find alternation of the perpetrators and the victims? 4) What direct social results (in particular economic, organizational oucomes) and indirect social oucomes (in particular in the area of attitudes, with further negative consequences) can be noted? What are the barriers hindering fighting against apparent actions and what do they consist in? Is it possible to fight apparent actions and in what conditions?" 9

8 J.A. Komeński (Comenius), Pampaedia, Zakład Narodowy im. Ossolińskich, Wydawnictwo Państwowe Wydawnictwo naukowe, Wrocław - Warsaw - Kraków - Gdańsk 1973, pp. 16-17.

${ }_{9}^{9}$ M. Dudzikowa, Działania pozorne w edukacji jako palacy problem. Wprowadzenie do książi (Apparent activities in education as a burning problem. Introduction to the book), [in:] Sprawcy i/lub ofiary działań pozornych w edukacji szkolnej (Perpetrators and/or Victims of Apparent Activity in School Education), ed. M. Dudzikowa, K. Knasiecka, Oficyna Wydawnicza „Impuls”, Kraków 2014, p. 24. 
The risk of an apparent action is such that it lures like a drug with the fact that the area of freedom is large and that I can use it whenever I want. "In the meantime a significant part of our choices and actions is not a result of free decisions, but of this or that addiction. We act in our lives as puppets pulled by the strings by various habits. At the same time we are not aware of it, so we are even more exposed to them". ${ }^{10}$ We are exposed to apparent actions, playing with them, getting tangled in more and more dependencies. According to Lutyński apparent actions have six basic features: "1. They are officially deemed to be significant for the performance of some socially important objective; 2 . They fail to meet this objective in reality; 3 . The given community commonly knows of their worthlessness; 4. It is private knowledge, not expressed officially; 5. Their real function consists in their existence only; 6 . They always contain some element of fiction, referring to their course or objective". ${ }^{11}$

Lutyński also distinguished four mechanisms that foster the occurrence of apparent actions in a centrally controlled system. They constitute: "1) an organizational and decision-making mechanism inherent in the organizational and institutional structure and at the same time in the decision-making system; 2) axiological mechanism, i.e. regarding the sphere of values, referring to values that are recognized but unrealized for various reasons (for example, they usually stem from other social systems or from earlier historical periods, and are adopted by acclamation and planned / controlled occurrences); 3) the mechanism of compulsory enforcement of unrealistic provisions, which is triggered by an increase in regulations and provisions associated with the expansion and bureaucracy of

${ }^{10}$ A. Dodziuk, Nałogowy człowiek w nałogowym społeczeństwie (An Addictive Person in an Addictive Society), [in:] A. Dodziuk, L. Kapler, Nałogowy człowiek (An Addictive Person), Instytut Psychologii Zdrowia, Polskie Towarzystwo Psychologicznego, Warsaw 2007, p. 9.

11 J. Lutyński, Działania pozorne (Apparent actions), [in:] J. Lutyński Nauka i polskie problemy. Komentarz socjologa (Science and Polish Issues. A Sociologist's Commentary), Państwowy Instytut Wydawniczy, Warsaw 1990, p. 105. 
various divisions of the system and all activities of the authorities; 4) a supposedly pragmatic mechanism, causing apparent actions organized by the authorities, aimed at solving a swollen social problem". ${ }^{12}$

In my opinion, this typology reveals (uncovers, exposes) something very important. Namely, violence hidden behind an appearance. Violence, which - as Andrzej Zybertowicz claims - "plays a constructive role in the process of creating, disseminating and functioning of knowledge in society and it is impossible to explain knowledge without placing it in the centre of attention" ${ }^{13}$ Slavoj Žižek draws attention to two types of violence: subjective and objective. "The first one is what we used to associate with violence - it comes down to aggression, cruelty, it is expressed in "crimes, social unrest or international conflicts". 14 These spectacular manifestations of brutality are accompanied by the second type of violence that very often goes unnoticed, i.e. objective violence. It can be present in perfectly organised communities that is where (paradoxically) "there seems to be order". ${ }^{15}$ It is a form of oppression that results from the operation of various types of systems, ranging from the language system to economic and political systems. Žižek distinguishes two types of objective violence: "The first one is symbolic violence, inscribed in language and its forms, which is called by Heidegger "the human house of being" ${ }^{16}$ Žižek calls the other type of objective violence a systemic violence. It is the characteristic feature of all systems whose task is to maintain the level of normality in a society. We do not see it because it organizes reality (it is con-

12 J. Lutyński, ibidem 1990, p. 106.

13 A. Zybertowicz, Przemoc i poznanie, Studium z nie-klasycznej socjologii wiedzy (Violence and Cognition: A Study in Non-classical Sociology of Knowledge), Wydawnictwo Uniwersytetu Mikołaja Kopernika, Torun 1995, p. 14.

14 S. Žižek, Przemoc. Sześć spojrzeń z ukosa (Violence: Six Sideways Reflections), Muza, Warsaw 2010, p. 5.

15 S. Žižek, ibidem 2010, p. 6.

16 Ibidem, p. 6. 
tained in social, economic and political systems). ${ }^{17}$ The last sentence fits perfectly with the concept of "bad faith," which consists " $(.$.$) in$ creating the appearance that something is necessary while in reality it is voluntary. (...) Anyone who says: "I have no choice" in relation to what their social role requires of them, persists in "bad faith." We can easily imagine the circumstances in which this statement will be true to the extent that there is no choice in this particular role. Nevertheless, an individual has a choice - to abandon this role. ${ }^{18}$ It is violence in our world that is a more primitive reality than the false and true or good and evil. Violence in its various forms - physical and mental. A stronger personality subordinates the weaker one and de facto sets the values according to which social communication takes place. ${ }^{19}$

Violence is also a part of the educational system. As Pierre Bourdieu pointed out, that is one of the most spectacular expressions of symbolic violence. For, as this thinker claims, the principle of all violence is its ability to hide under the appearance of objectivity or obviousness (emphasis added by M. Jabłoński). In pedagogical activity, which seems to be treated as a prototype of any social activity that enforces spontaneity, Bourdieu claims, there is a double arbitrariness: not only is the enforcing authority, but the enforced content of teaching is equally arbitrary. ${ }^{20}$ Appearance covers the homology between the school monopoly on legitimate symbolic violence and the state monopoly on legitimate physical violence. ${ }^{21}$ Appearance unfortunately justifies systemic violence under the cover of the slogan: There is nothing I can do, this is the system that we have!!! (sic!).

17 This is what Jan Lutyński showed in his typology in points 3 and 4.

18 P.L. Berger, Zaproszenie do socjologii (Invitation to Sociology), Państwowe Wydawnictwo Naukowe, Warsaw 1988, pp. 149-150.

19 Jasiński, Zagubiony etos (The Lost Ethos), Miesięcznik Literacki, no. 7-8, 1987, p. 131.

${ }^{20}$ E. Zakrzewska-Manterys, Upośledzeni umysłowo. Poza granicami człowieczeństwa (Mentally Handicapped. Beyond the Borders of Humanity), Wydawnictwo Uniwersytetu Warszawskiego, Warsaw 2010, p. 161.

21 See: P. Bourdieu, J.-C. Passeron, Reprodukacja. Elementy teorii systemu nauczania (Reproduction. Elements of the Educational System Theory), PWN, Warsaw 2006, p. 69. 


\section{On systemic violence in the approach to disability}

In relation to people with disabilities, appearances can be seen as systemic violence. "Because a development matrix is applied to the lives of people with disabilities, as proposed by the great theoreticians of developmental psychology (...) I consider this way of using the development approach to study the adulthood of people with disabilities to be a waste of opportunity to create a new paradigm in studying disability issues, as well as such a theoretical procedure which cannot contribute to progress in providing effective assistance to the development of persons".22 And it is "(...) the pathology that fulfils the adjustment function, is the reaction to factors harmful to the system and a way to deal with it in order to keep the system alive" ${ }^{23}$ This raises the question of how do we actually perceive people with disabilities. Who or what do we see first seeing them in the street, in a shop or at school? Is it an individual first or their disability? Is it possible that this "defectological" point of view sends us the whole picture of a given reality? Or maybe the disabled are perceived as a minority group, and the disability as a difference / otherness, rather than lack of something. Therefore, all members of a given society have the right to live independently in a community, with mutual recognition of differences and the development of coexistence skills for all members of the society?24

22 S. Kowalik, Pomoc w dochodzeniu i utrzymaniu własnej dorosłości przez osoby niepetnosprawne (Helping disabled people to discover and retain their own adulthood), [in:] Niepetnosprawność w zwierciadle dorostości (Disability in the Mirror of Adulthood), ed. R. Kijak, Oficyna Wydawnicza „Impuls”, Kraków 2012, p. 39.

${ }_{23}$ M. Kościelska, Oblicza upośledzenia (The Faces of Impairment), PWN, Warsaw 1995, p. 197.

24 See: G. Szumski, Edukacja inkluzyjna - geneza, istota, perspektywy (Inclusive Education - Genesis, Essence, Perspectives), Kwartalnik Pedagogiczny 2006, no. 1, pp. 96-100; cf. J. Skibska, M. Warchał, Edukacja inkluzyjna dziecka niepetnosprawnego w szkole ogólnodostępnej a integracja spoteczna Edukacja jutra w kontekście wyzwań wspótczesności (Inclusive education of disabled children in public school and social integration. Education of tomorrow in the context of challenges in contemporary times), [in:] Edukacja jutra w kontekście wyzwań wspótczesności dostępnej a integracja społeczna (Education of Tomorrow in the Context of Challenges of the Accessible Modernity and Social Integration), eds. K. Denek, 
Clashing with this multitude of opinions, another question arises of whether we have to define everything and everyone. Seeing that often by playing with concepts we miss the sense of an individual, the meaning of life. Is this peculiar "game" of detailed specification and continuous redefinition not an apparent action? On the other hand, an attempt to clarify the terminology may serve as a tool for explaining sources and becomes a means enabling theoretical justification and at the same time practical exposition of actual social practices used for oppressive purposes towards people with disabilities by pushing them into various apparent activities. ${ }^{25}$

When examining the legal provisions relating to special education and students with disabilities, Agnieszka Olechowska argues that based on the conducted critical analysis of the provisions of selected legal acts, the provisions dominate that are characteristic of the paradigm of biological perception of disability, which may establish negative stereotypes and stigmatization of students with special needs. ${ }^{26}$ If the provisions in legal acts are "closer" to the biological paradigm than to the social one, then the question is whether and to what extent the program basis described and analysed by me was subject to public consultation? If it was, what entities commented on it and what resulted from their commentaries in favour of changing the quality of education for students with intellectual disabilities in terms of the competences studied, i.e. social and civic? I sent my query to the Ministry of National Education and on 1 March 2019 I received a reply saying that the basis had been sent to 96 entities $^{27}$ including the Polish Ombudsman, the Ombudsman

A. Kamieńska, W. Kojs, P. Oleśniewicz, Oficyna Wydawnicza „HUMANITAS”, Sosnowiec 2012, pp. 369-386.

25 See: Człowiek z niepetnosprawnościa w rezerwacie przestrzeni publicznej (People with Disabilities in the Reserve of Public Space), ed. Z. Gajdzica, Oficyna Wydawnicza „Impuls," Kraków 2013; Zakrzewska-Manterys, ibidem 2010; Krause, ibidem, 2010.

26 A. Olechowska, Paradygmaty pedagogiki w oficjalnym dyskursie pedagogicznym jako narzędziu polityki edukacyjnej (Paradigms of Pedagogy in the Official Pedagogical Discourse as a Tool of Educational Policy), "Zarządzanie Publiczne” 1(41), 2018, p. 59.

${ }^{27}$ Full list of entities to which the project has been sent <https://legislacja. rcl.gov.pl/docs//501/12293659/12403175/12403176/dokument265873.pdf> (added on 30.03.2019). 
for Children, Committee on Education studies of the Polish Academy of Sciences, Civic Education Association, Polish Association for Persons with Mental Disabilities (currently Polish Association for Persons with Intellectual Disability), Foundation for Social Diversity, Foundation in Support of Local Democracy, or Polish Teachers' Union. An interesting, and, in my opinion, sad thing is that out of the above-mentioned institutions it was only the Polish Teachers' Union that sent their comments and proposed changes. ${ }^{28}$

Following this lead, the question should be asked who falls victim to the systemic violence Žižek is writing about? Who does not even try to change reality - in this case the formal and legal reality? Thanks to observing the reality associated with the system of education of students with disabilities, analysis of academic literature as well as laws and ordinances, I shall try to present an example of apparent activities at the macro (national) level in the area of special education of students with moderate and severe intellectual disability on the basis of a critical analysis of the core curriculum.

\section{Critical analysis of the core curriculum}

The purpose of the analysis of the core curriculum was to identify the content pertaining to social and civic competences as well as its potential educational outcomes. "There is no sharp distinction between social and civic competences. As it is, their meanings often overlap" ${ }^{29}$ Social competences are a broader category, while civic competences constitute a subset thereof. If we refer to the metaphor of base and superstructure, we can say that social competences are

${ }^{28}$ See: <https://legislacja.rcl.gov.pl/docs//501/12293659/12403175/12403178/ dokument272179.pdf> (added on 30.03.2019).

${ }^{29}$ Kompetencje spoteczne $i$ obywatelskie. W podstawach programowych ksztatcenia ogólnego. Analiza krytyczna (Social and Civic Competences. In the Core Curriculum of General Education. A Critical Analysis), eds V. Kopińska, H. Solarczyk-Szwec, Wydawnictwo Naukowe Uniwersytetu Mikołaja Kopernika, Toruń 2017, p. 11. 
a base, while civic competences are a superstructure. This is yet another reason to analyse them together. ${ }^{30}$

The method employed to collect data for this study was a review of secondary sources. ${ }^{31}$ The study sample was the primary school core curriculum - for pupils with moderate or severe intellectual disability. 32

The following question was posed: What learning outcomes are observed in special education core curricula as regards social and civic competences? For my research I selected primary school core curriculum, designed for pupils with moderate or severe intellectual disability, which constituted Appendix no. 3 to the Regulation of 24th February 2017, item 356. In this kind of school there are: 1) educational classes, including: a) individual and social functioning, b) classes focused on communication, c) classes focused on creativity, d) physical education, e) ethics, 2) remedial classes. The type of remedial classes is defined in the individual educational and therapeutic programme for a specific pupil, designed on the basis of recommendations included in the document confirming the need for special education and on the outcome of the multifaceted specialist functioning assessment. ${ }^{33}$ What we read in the core curriculum is: "the teaching content has been designed as an open set of social situations and roles the pupil might be faced with. The teaching content may exceed the abovementioned areas, depending on the pupils' needs. The teacher has a right to choose (also narrow down or expand) the teaching content, which is beneficial for the pupil's development, with special attention paid to the pupil's autonomy and dignity". ${ }^{34}$ This is why the analysed core curriculum was treated holistically, without dividing the content into individual classes.

30 Cf. V. Kopińska, H. Solarczyk-Szwec, ibidem 2017.

${ }^{31}$ K. Rubacha, Metodologia badań nad edukacja (Methodology of Research on Education), Wydawnictwa Akademickie i Profesjonalne, Warsaw 2008, pp. 157-164

32 Appendix no. to the Regulation of the Minister of National Education of 14 February 2017, item 356, on the core curriculum for primary schools for students with moderate or severe intellectual disabilities.

33 Ibidem.

34 Ibidem. 
What became the starting point for the search for main analytical categories related to social and civic competences was Appendix to the Recommendation of the European Parliament and the Council of 18th December 2006 on key competences for lifelong learning - Key competences in lifelong learning - European Frame of Reference (L/394)..$^{35}$ According to the Frame, the goal of civic education is to make sure the citizens:

- know their civic rights and obligations, know what a citizen may demand from public institutions, but also what our obligations are towards our fellow citizens;

- know such notions as human rights, are able to recognise signs of human right infringement, but also actively oppose such breaches and sympathize with victims of such infringements.

Key social competences in three areas include:

Knowledge: understanding the rules and principles of behaviour generally accepted in various societies and circles (e.g. at work, school, in the office); knowledge of the basic notions related to people, groups, professional organizations; understanding the principles of gender equality and non-discrimination; knowledge and understanding of multicultural, social and economic dimensions of European societies. Competences: constructive communication in various environments, with people of different origin, with various interests, views; showing tolerance; expressing and understanding various points of view; negotiating combined with the ability to create the climate of trust; coping with stress and frustration and expressing them in a constructive manner. Attitudes: being open to cooperation, assertiveness, righteousness; being interested in social and economic development; appreciating diversity and respecting others, as well as being prepared to overcome prejudice and reaching compromise. ${ }^{36}$

35 Given the limited length of the text, I will only mention the main objectives concerning social and civic competences.

36 See: M. Jabłoński, Edukacja obywatelska. Krytyczna analiza statutów podmiotów prowadzacych Warsztaty Terapii Zajęciowej (Civic Education. Critical analysis of the statutes of entities running Occupational Therapy Workshops). „Niepełnosprawność. Dyskursy pedagogiki specjalnej” no. 32/2018, pp. 276-292. 
Social and civic competences in the document under analysis are understood in a very broad sense, both from the perspective of national citizenship and the sum of values such as responsibility, awareness, caring for others and the immediate environment. They constitute a kind of clasp connecting a certain set of attitudes and values created as desirable for a given society. What I present below is a table containing results of the analysis of the base content.

Table 1. Most numerous analytical categories (learning outcomes) in the core curriculum for primary schools for students with moderate to severe intellectual disabilities

\begin{tabular}{|c|c|c|}
\hline \multicolumn{3}{|l|}{ Area of knowledge } \\
\hline \multirow[b]{2}{*}{ Analytical category/learning outcome } & \multicolumn{2}{|c|}{$\mathrm{N}=44$} \\
\hline & occurs & $\begin{array}{c}\text { does } \\
\text { not occur }\end{array}$ \\
\hline Knowledge regarding forms of communication & 3 & 41 \\
\hline $\begin{array}{l}\text { Knowledge regarding assertiveness and its meaning in } \\
\text { interpersonal contacts }\end{array}$ & 3 & 41 \\
\hline $\begin{array}{l}\text { Understanding of codes of conduct and rules of conduct } \\
\text { generally accepted in various communities and environ- } \\
\text { ments }\end{array}$ & 2 & 42 \\
\hline $\begin{array}{l}\text { Knowledge regarding assertiveness and its meaning in } \\
\text { interpersonal contacts }\end{array}$ & 1 & 43 \\
\hline $\begin{array}{l}\text { Knowledge regarding empathy and its meaning in interper- } \\
\text { sonal contacts }\end{array}$ & 1 & 43 \\
\hline $\begin{array}{l}\text { Knowledge regarding non-governmental organizations and } \\
\text { volunteering work }\end{array}$ & 1 & 43 \\
\hline Knowledge regarding environmental protection & 1 & 43 \\
\hline $\begin{array}{l}\text { Knowledge regarding behaviour in crisis situations (life- } \\
\text { and health-threatening) }\end{array}$ & 1 & 43 \\
\hline $\begin{array}{l}\text { Knowledge regarding how to ensure one's physical and } \\
\text { mental health (including how a healthy lifestyle can con- } \\
\text { tribute to this) }\end{array}$ & 1 & 43 \\
\hline Knowledge regarding human rights & 1 & 43 \\
\hline Knowledge regarding human rights protection & 1 & 43 \\
\hline
\end{tabular}




\begin{tabular}{|c|c|c|}
\hline \multicolumn{3}{|l|}{ Area of knowledge } \\
\hline \multirow[b]{2}{*}{ Analytical category/learning outcome } & \multicolumn{2}{|c|}{$\mathrm{N}=44$} \\
\hline & occurs & $\begin{array}{c}\text { does } \\
\text { not occur }\end{array}$ \\
\hline $\begin{array}{l}\text { Knowledge regarding (other than elections) ways/forms of } \\
\text { participation in decision-making processes at local level }\end{array}$ & 1 & 43 \\
\hline \multicolumn{3}{|l|}{ Area of competence } \\
\hline Communication skills & 5 & 39 \\
\hline $\begin{array}{l}\text { Ability to act in accordance with the procedures and poli- } \\
\text { cies prevailing in different environments }\end{array}$ & 4 & 40 \\
\hline $\begin{array}{l}\text { Ability to express one's own opinion, to present one's own } \\
\text { ideas in writing and/or in speech }\end{array}$ & 3 & 41 \\
\hline $\begin{array}{l}\text { Ability to act in accordance with the procedures in force in } \\
\text { various institutions and organisations }\end{array}$ & 2 & 42 \\
\hline $\begin{array}{l}\text { Ability to cope with stress and frustration and with express- } \\
\text { ing them in a constructive way }\end{array}$ & 2 & 42 \\
\hline Ability to express emotions & 1 & 43 \\
\hline Ability to distinguish between fact and opinion & 1 & 43 \\
\hline Ability to make public appearances & 1 & 43 \\
\hline Ability to understand different points of view & 1 & 43 \\
\hline Ability to identify and discuss one's own problems & 1 & 43 \\
\hline $\begin{array}{l}\text { Ability to act in accordance with the procedures in force in } \\
\text { various institutions and organisations }\end{array}$ & 1 & 43 \\
\hline \multicolumn{3}{|l|}{ Area of attitude } \\
\hline Willingness to act autonomously & 3 & 41 \\
\hline Sense of belonging to the environment & 1 & 43 \\
\hline $\begin{array}{l}\text { Willingness to take responsibility for the consequences of its } \\
\text { own actions }\end{array}$ & 1 & 43 \\
\hline
\end{tabular}

The table lists the most common analytical categories related to social and civic competences included in the core curriculum. The most represented are the outcomes in the area of competence (2237), where the most common analytical categories are: communication

37 The total number of outcomes in a given area. 
skills (5), the ability to act in accordance with the procedures and policies prevailing in different environments (4) and the ability to express one's own opinion, to present one's own ideas in speech and/or writing (3). What follows in terms of the number of outcomes is the area of knowledge (17) in which the categories of knowledge regarding forms of communication and of knowledge regarding assertiveness and its meaning in interpersonal contacts occurred with the same frequency (3), while the category of understanding of codes of conduct and rules of conduct generally accepted in various communities and environments occurred (2) times. In the attitude area (4), the willingness to act autonomously occurs (3) times. As one can see, communication is the category that dominates in the areas of knowledge and competence.

\section{Conclusions instead of summary}

Approaching the analysis of the core curriculum of primary school - for pupils with intellectual disability at a moderate or significant degree that constitutes Appendix No. 3 to the Regulation, at the beginning I compared: first of all the core curriculum of general education primary school, which consists of 200 pages, and for primary education of special needs school, which consists of 15 pages. Both the disproportion and the number of the identified requirements referring to the social and civil competences are puzzling. The core curriculum of general education contains 569 identified analytical categories. ${ }^{38}$ My analysis contains 44 .

I am aware that such a comparison is not entirely valid as the curricula were studied in a different way. However the basis for both were the Guidelines of the European Parliament and of the Council of $18^{\text {th }}$ December 2006 on key competences in the process of life-long learning. I know that the method of analysis itself as well as interpretation of the results may be in a way subject to a discus-

38 After: V. Kopińska, H. Solarczyk-Szwec, ibidem, 2017, p. 216. 
sion. However the quantitative difference is huge. If I were to recommend the most significant, though absent, competences in the areas of knowledge, competences and attitudes in the analysed curriculum, they would certainly be in the area of knowledge: knowledge on the forms of citizens' objection; knowledge and application of the term "democracy"; knowledge and application of the term "justice"; knowledge and application of equality. ${ }^{39}$ In the second area, competences, I consider the following missing: skills to define own problems and talking about them; the skill to solve conflicts; the skill to assess own actions; the skill to assess the actions of other persons; the skill to undertake actions to guarantee physical and mental health, to protect environment. Whereas in the area of attitudes, we fail to find such competences as: respecting values and privacy of other persons; respecting human rights (freedom, equality, dignity); conviction about the meaning of mental and physical health and about the necessity to guarantee oneself the optimum level of physical and mental health.

The feeling of deficiency and peculiar "bleakness" is additionally strengthened by one significant fact that the process of acquiring social and civic competences by the pupils in general education schools is supported by their participation in the student government. In the case of special needs school for pupils with moderate and significant intellectual disability the student government under the Regulation of the Ministry of National Education of 23rd February 2007 is not established. ${ }^{40}$ There arises a question whether such actions are not apparent. I believe that they are apparent actions that also infringe e.g. Article 32 of the Constitution of the Republic of Poland of 2nd April 1997, which states in item 1. "All people are equal. All people have the right to equal treatment by public authorities;" whereas in item 2. "Nobody can be discriminated against in the political, social or economic life for any reason" ${ }^{41}$

39 Ibidem p. 98.

40 See: Journal of Laws of 23 March 2007. No. 52, item 347.

41 There are studies on students government in special institutions conducted within the framework of NCN Miniature 2 Students government and social inclu- 
"This causes that the group of people often (...) have no competences for any participation in these spheres of public and cultural life that require communication with the aid of symbols".42 The beautiful and momentous slogans like those included in the core curriculum and regarding the UN Convention on the Rights of the Disabled Persons, where Article 19 talks of teaching independent life " (...) the society of the State of a Party to this Convention deems equal the right of all the disabled persons to live in a society and the right to make choices equally with other persons and shall undertake efficient and proper means to facilitate full use of such right by the disabled and their full inclusion and participation in the society". ${ }^{43}$ There arises a question of how the pupils acquire social and civic rights if they have no possibility to exercise the right to create student governments in their schools. I also believe that the Convention is not respected. Is not speaking of equality just aapparent? The State allowed for creation and functioning of the student governments only in the selected schools and only the capable pupils and lightly disabled pupils. It is still the cultural reproduction that strengthens social inequality. ${ }^{44}$

On the other hand, we can see that just the legal regulations, the top-down paradigm character of the areas of knowledge actually fail to work. At the utmost, they make everyone the slaves of the system, the system of areas colonised by healthy, strong persons throwing from time to time "the sops of freedom" to the disabled, not necessarily according to their needs. As a result of the analysis of the above study issue there arise five questions on the apparent actions of "authorities" (parents, teachers, head masters, politicians,

sion in special education, the results of which I plan to publish at the end of year 2019.

42 Z. Kwieciński, Tropy - ślady - próby. Studia i szkice z pedagogiki pogranicza (Clues Traces - Trials. Studies and sketches of borderline pedagogy), Edytor, Torun 2000, p. 164.

43 See: <http:/ / konwencja.org/konwencja/> [date of access: 31 Jan. 2019 (added on 30.03.2019)].

44 See: P. Bourdieu, J.-C. Passeron, Repordukacja. Elementy teorii systemu nauczania (Reproduction. Elements of the Educational System Theory), PWN, Warsaw 2006. 
society). 1) Initiation - which regards how the study process starts and whose interests and methods determine and define their results. The capable persons or the disabled? 2) Benefits - the question who will take direct advantages from the studies and will by any chance no one suffer? 3) Authorization - it is the question about power that we give to our texts. Is it not so that the knowledge of the disabled is diminished so as to strengthen the knowledge, practice and processes of the capable persons? 4) Responsibility - who takes responsibility for the processes in education: the authorities, the researchers, the teachers or perhaps the pupils? Who exercises control over initiation, procedures, assessments, building texts and distribution of newly-built knowledge? 5) Representation - whose tests deliver the right picture of reality? ${ }^{45}$

Perhaps it is still so that in the name of some indeterminate good the still "authoritative" voice of an "expert" displaces the experience of the disabled persons expressing it in terms defined by such an "expert"? In the afore-discussed example of apparent actions occurring in the area of special education, I can see marginalization of cognitive values, one-sidedness of perceiving the problems of special needs education, chaos and lack of reflectivity.

\section{Bibliography}

[1] Berger P.L., Zaproszenie do socjologii (Invitation to Sociology). PWN, Warszawa 1988.

[2] Bishop R., Maori K., Przezwyciężyć neokolonializm w badaniach społecznych (Freeing ourselves from neocolonial domination in research), [in:] Metody badań jakościowych (Qualitative Research Methods) Vol. 1 and Vol. 2, eds. Norman K. Denzin, Yvonna S. Lincoln, PWN, Warszawa 2010.

[3] Bourdieu P., Passeron J.-C., Repordukacja. Elementy teorii systemu nauczania (Reproduction. Elements of the Educational System Theory), PWN, Warszawa 2006.

45 R. Bishop, K. Maori, Przezwyciężyć neokolonializm w badaniach społecznych (Freeing ourselves from neocolonial domination in research), [in:] Metody badań jakościowych (Qualitative Research Methods) Vol. 1 and Vol. 2, eds. Norman K. Denzin, Yvonna S. Lincoln, Warsaw, PWN, 2010, pp. 167-205. 
[4] Chrzanowska I., Problemy edukacji dzieci i młodzieży z niepetnosprawnością: regionalna specyfika czy ogólnopolska tendencja (Educational Problems of Children and Young People with Disabilities: Regional Specificity or National Tendency), Oficyna Wydawnicza „Impuls”, Kraków 2010.

[5] Dodziuk A., Nałogowy człowiek w nałogowym społeczeństwie (An Addictive Person in an Addictive Society), [in:] eds. A. Dodziuk, L. Kapler Nałogowy człowiek (An Addictive Person). Warszawa: Instytut Psychologii Zdrowia, Polskie Towarzystwo Psychologicznego, Warszawa 2007.

[6] Dudzikowa M., Dziatania pozorne w edukacji jako palacy problem. Wprowadzenie do ksiażki (Apparent activities in education as a burning problem. Introduction to the book), [in:] Sprawcy i/lub ofiary dziatań pozornych w edukacji szkolnej (Perpetrators and/or Victims of Apparent Activity in School Education), ed. M. Dudzikowa, K. Knasiecka-Flabierska, Oficyna Wydawnicza „Impuls”, Kraków 2014.

[7] Faure E., Uczyć się, aby być (Learning to Be. The World of Education Today on Tomorrow), PWN, Warszawa 1975.

[8] Rozwój i funkcjonowanie osób niepetnosprawnych. Konteksty edukacyjne i prawne (Development and Functioning of People with Disabilities. Educational and Legal Contexts), ed. Z. Gajdzica, Oficyna Wydawnicza „Impuls”, Kraków 2007.

[9] Człowiek z niepełnosprawnością $\mathrm{w}$ rezerwacie przestrzeni publicznej (People with Disabilities in the Reserve of Public Space), ed. Z. Gajdzica, Oficyna Wydawnicza „Impuls”, Kraków 2013.

[10] Jabłoński, M., Edukacja obywatelska. Krytyczna analiza statutów podmiotów prowadzacych Warsztaty Terapii Zajęciowej (Civic Education. Critical analysis of the statutes of entities running Occupational Therapy Workshops). „Niepełnosprawność. Dyskursy pedagogiki specjalnej" no. 32/2018, pp. 276-292.

[11] Jachimczak B., Gotowość nauczycieli szkót ogólnodostępnych do pracy z uczniem o specjalnych potrzebach edukacyjnych (Willingness of teachers at public schools to work with students with special educational needs), [in:] Miejsce Innego we wspótczesnych naukach o wychowaniu - wyzwania praktyki (The Place of Other in Modern Educational Sciences. The Challenges of Practice), ed. I. Chrzanowska, B. Jachimczak, Wydawnictwo Satori, Łódź 2008.

[12] Jasiński B., Zagubiony etos (The Lost Ethos), Miesięcznik Literacki, nos. 7-8, 1987, pp. 125-134.

[13] Komeński (Comenius) J.A., Pampaedia, Zakład Narodowy im. Ossolińskich, Wydawnictwo Państwowe Wydawnictwo naukowe, Wrocław - Warszawa Kraków - Gdańsk 1973.

[14] Constitution of the Republic of Poland of 2 April 1997, Wydawnictwo Sejmowe, Warsaw 2003.

[15] The UN Convention on the Rights of Persons with Disabilities was adopted by the General Assembly of the United Nations (UN) on 13 December 2006.

[16] Kompetencje spoteczne i obywatelskie. W podstawach programowych ksztatcenia ogólnego. Analiza krytyczna (Social and Civic Competences. In the Core Curriculum of 
General Education. A Critical Analysis), ed. V. Kopińska, H. Solarczyk-Szwec, Wydawnictwo Naukowe Uniwersytetu Mikołaja Kopernika, Torun 2017.

[17] Kościelska M., Oblicza upośledzenia (The Faces of Impairment), PWN, Warszawa 1995.

[18] Kowalik S., Pomoc w dochodzeniu i utrzymaniu wtasnej dorostości przez osoby niepetnosprawne (Helping disabled people to discover and retain their own adulthood), [in:] Niepetnosprawność w zwierciadle dorostości (Disability in the Mirror of Adulthood), ed. R. Kijak, Oficyna Wydawnicza „Impuls”, Kraków 2012.

[19] Krause A., Wspótczesne paradygmaty pedagogiki specjalnej (Contemporary Paradigms of Special Needs Education), Oficyna Wydawnicza „Impuls”, Kraków 2010.

[20] Kwieciński Z., Tropy-ślady-próby. Studia i szkice z pedagogiki pogranicza (Clues Traces - Trials. Studies and sketches of borderline pedagogy), „Edytor”, Torun 2000.

[21] Lutyński J., Działania pozorne (Apparent actions), [in:] Nauka i polskie problemy. Komentarz socjologa (Science and Polish Issues. A Sociologist's Commentary), J. Lutyński, Państwowy Instytut Wydawniczy, Warszawa 1990.

[22] Olechowska A., Paradygmaty pedagogiki w oficjalnym dyskursie pedagogicznym jako narzędziu polityki edukacyjnej (Paradigms of Pedagogy in the Official Pedagogical Discourse as a Tool of Educational Policy), "Zarządzanie Publiczne" 2018, 1(41) pp. 59-74.

[23] Pawelczak K., Niepetnosprawność - Inna jakość, która ma prawo taka pozostać (Disability. Another quality that has the right to remain as it is), "Studia Edukacyjne" 2012, no. 25/2012, pp. 150-157.

[24] Parys K., Zjawisko pozoru w systemie kształcenia uczniów niepetnosprawnych - próba identyfikacji i propozycje rozwiazań (An Attempt at Identifying the Phenomenon of Pretense in the Education of Students with Disabilities and Proposals for Solutions), „Interdyscyplinarne Konteksty Pedagogiki Specjalnej” 2014, no. 4/2014, pp. $29-55$

[25] Regulation of the Ministry of Education of 23 February 2007, No. 53, item 347, on the types of schools and institutions in which no student self-government is established.

[26] Rubacha K., Metodologia badań nad edukacja (Methodology of Research on Education). Wydawnictwa Akademickie i Profesjonalne, Warszawa, 2008, pp. 157-164

[27] Skibska J., Warchał M., Edukacja inkluzyjna dziecka niepetnosprawnego w szkole ogólnodostępnej a integracja społeczna Edukacja jutra w kontekście wyzwań wspótczesność (Inclusive education of disabled children in public school and social integration. Education of tomorrow in the context of challenges in contemporary times), [in:] Edukacja jutra w kontekście wyzwań wspótczesności dostępnej a integracja społeczna (Education of Tomorrow in the Context of Challenges of the Accessible Modernity and Social Integration), eds. K. Denek, A. Kamieńska, W. Kojs, P. Oleśniewicz, Oficyna Wydawnicza „HUMANITAS”, Sosnowiec 2012. 
[28] Songin M.Z., porzadkowanego punktu widzenia (From an Orderly Point of View), [in:] Humanistyka i dominacja. Oddolne doświadczenia społeczne w perspektywie zewnętrznych rozpoznań (Humanities and Dominance. Bottom-up social experiences in the perspective of external diagnoses), eds. T. Rakowski, A. Malewska-Szałygin, Colloquia Humaniorum, Warszawa 2011.

[29] Szumski G., Edukacja inkluzyjna - geneza, istota, perspektywy (Inclusive Education Genesis, Essence, Perspectives), „Kwartalnik Pedagogiczny” 2006, no. 1, pp. 96-100.

[30] Śliwerski B., Meblowanie szkolnej demokracji (Furnishing School Democracy), Wolters Kluwer, Warszawa 2017.

[31] Recommendation of the European Parliament and of the Council of 18 December 2006 on key competences for lifelong learning, published in the Official Journal of the European Union of 30 December 2006.

[32] Appendix no. to the Regulation of the Minister of National Education of 14 February 2017, item 356, on the core curriculum for primary schools for students with moderate or severe intellectual disabilities.

[33] Zakrzewska-Manterys E., Upośledzeni umysłowo. Poza granicami człowieczeństwa (Mentally Handicapped. Beyond the Borders of Humanity), Wydawnictwo Uniwersytetu Warszawskiego, Warsaw 2010.

[34] Zybertowicz A., Przemoc i poznanie, Studium z nie-klasycznej socjologii wiedzy (Violence and Cognition: A Study in Non-classical Sociology of Knowledge), Wydawnictwo Uniwersytetu Mikołaja Kopernika Torun 1995.

[35] Žižek S., Przemoc. Sześć spojrzeń z ukosa (Violence: Six Sideways Reflections), Muza, Warszawa 2010. 